\title{
Nullity of GSTT1/GSTM1 related to pesticides is associated with Parkinson's disease
}

\author{
Nulidade de GSTT1/GSTM1 relacionada à pesticidas associa-se com doença de Parkinson \\ Marcela Augusta de Souza Pinhel', Caroline Leiko Sado², Gabriela dos Santos Longo³, Michele Lima Gregório', \\ Gisele Sousa Amorim', Greiciane Maria da Silva Florim', Camila Montoro Mazeti', Denise Poltronieri Martins', \\ Fábio de Nazaré Oliveira ${ }^{3}$, Marcelo Arruda Nakazone ${ }^{4}$, Waldir Antonio Tognola ${ }^{5}$, Dorotéia Rossi Silva Souza
}

\begin{abstract}
Genetic and environmental factors affect the pathogenesis of Parkinson's disease (PD). Genetic variants of the enzyme glutathione S-transferases (GST) may be related to the disease. This study aimed to evaluate the influence of genetic variants of GST (GSTT1/GSTM1) and their association with the exposure to environmental toxins in PD patients. We studied 254 patients with PD and 169 controls. The GSTM1/GSTT1 variants were analyzed by polymerase chain reaction. We applied the Fisher's exact test and the $\chi^{2}$ test for statistical analysis ( $p<0.05$ ). The present and absence for GSTT1 and GSTM1 were similar in patients and controls. The null for GSTT1 and GSTM1 (0/0) and exposure to pesticides prevailed in patients (18\%) compared to controls $(13 \%, p=0.014)$. This study suggests the association between PD and previous exposure to pesticides, whose effect may be enhanced in combination with null for GSTT1/GSTM1.
\end{abstract}

Key words: Parkinson disease, glutathione transferase, polymorphism genetic, xenobiotics.

\section{RESUMO}

Fatores genéticos e ambientais influenciam a patogênese da doença de Parkinson (DP). Variantes genéticas das enzimas glutationa S-transferases (GST) parecem estar envolvidas com a doença. Os objetivos deste estudo foram avaliar a influência de variantes genéticas de GST (GSTT1/GSTM1) e sua associação com exposição a toxinas ambientais em pacientes com DP. Foram estudados 254 pacientes com DP e 169 controles. As variantes para GSTM1/GSTT1 foram analisadas por reação em cadeia da polimerase. Para análise estatística foram aplicados os testes de Fisher e do $\chi^{2}(p<0,05)$. Tanto a presença quanto a nulidade para GSTT1 e GSTM1 foram semelhantes em pacientes e controles. A nulidade para GSTT1 e GSTM1 (0/0) e contato com agrotóxicos prevaleceu nos pacientes (18\%) em relação aos controles (13\%, p=0,014). Este estudo sugere associação entre DP e contato prévio com agrotóxicos, cujo efeito parece potencializado em combinação com nulidade para GSTT1/GSTM1.

Palavras-Chave: doença de Parkinson, glutationa transferase, polimorfismo genético, xenobióticos.

Parkinson's disease (PD) is a progressive neurodegenerative disorder, clinically characterized by bradykinesia, rigidity, resting tremor, and postural instability. Early symptoms of PD are primarily due to the selective degeneration of dopaminergic neurons of the substantia nigra, innervating the neostriatum. The primary cause of PD is unknown, however, mitochondrial failure, oxidative stress and genetic factors, responsible for neurodegeneration in the substantia nigra are investigated hypotheses for the etiology of idiopathic $\mathrm{PD}^{1}$.

The progression of cell loss is thought to occur over a somewhat protracted period of time in a defined spatiotemporal manner, and the onset of PD symptoms is typically

\footnotetext{
Study carried out at Faculdade de Medicina de São José do Rio Preto (FAMERP), Núcleo de Pesquisa em Bioquímica e Biologia Molecular (NPBIM), São José do Rio Preto SP, Brazil.

${ }^{1}$ Biologist collaborator of FAMERP, São José do Rio Preto SP, Brazil;

${ }^{2}$ Medical Doctor of Universidade Federal de São Paulo (UNIFESP), São Paulo SP, Brazil;

${ }^{3}$ Medical Doctor of the Department of Neuroscience, FAMERP, São José do Rio Preto SP, Brazil;

${ }^{4}$ Medical Doctor, Hospital de Base/FAMERP, São José do Rio Preto SP, Brazil;

${ }^{5}$ Professor, FAMERP, São José do Rio Preto SP, Brazil.

Correspondence: Marcela Augusta de Souza Pinhel; Avenida Brigadeiro Faria Lima 5.416; 15090-000 São José do Rio Preto SP - Brasil;

E-mail: marcelapinhel@yahoo.com.br

Support: Fundação de Amparo à Pesquisa do Estado de São Paulo (FAPESP), Processes n 2008/53950-8 and 2009/18476-6, and Faculdade de Medicina de São José do Rio Preto (FAMERP).

Conflict of interest: There is no conflict of interest to declare.

Received 05 October 2012; Received in final form 18 March 2013; Accepted 25 March 2013.
} 
insidious. Biological models suggest that the progression of PD includes a long pre symptomatic period, thus there is significant potential for interventions that could slow or even arrest PD at this stage of the disease. However, there is currently no appropriate diagnostic test or biomarker that can identify this pre symptomatic population².

Currently, 6.3 million individuals, which represent $1 \%$ of the world population older than 65 years, are diagnosed with PD, and by 2030 this number may increase to 9.3 million $^{3.4}$. In Brazil, statistics show PD's prevalence of 150/200 for every 100.000 individuals and annual incidence of 20/100,000 cases ${ }^{5}$.

Central nervous system is particularly vulnerable to oxidative stress, due to factors such as high levels of oxygen, low concentration of antioxidants and their related enzymes. It demands a high level of energy and there are polyunsaturated lipids that tend to undergo oxidation. Moreover, iron particles may accumulate with advancing age and become a strong catalyzer in the formation of oxidative species, including free radicals ${ }^{6}$. Consequently, genetic predisposition combined with environmental risk factors may be the cause of the nigrostriatal cells degeneration ${ }^{7}$. Accumulation of such reactive substances in dopaminergic neurons may cause pathophysiological changes in the brain of PD patients, increased formation of reactive oxygen species and decrease of the antioxidant capacity of the tissue ${ }^{8}$.

It has been suggested that polymorphism in enzymes involved in oxidative metabolism and detoxification could be involved in predisposition to PD. Studies have hypothesized that individuals with poor metabolizing status, based on cytochrome P4502D6 (CYP2D6) genotype could be at risk to PD', though inconsistencies have been reported in the literature ${ }^{10}$. Similarly, polymorphism in enzymes, which generate free radicals or those involved in dopamine neurotransmission such as cytochrome P450 2E1 (CYP2E1), glutathione S-transferases (GST), superoxide dismutase (MnSOD), monoamine oxidase-B (MAO-B), dopamine receptor D2 (DRD2) and dopamine transporter (DAT) which are known to interact with environmental exposures, could be implicated in the pathogenesis of $\mathrm{PD}^{1,11}$.

GST may modify PD risk, since PD is more common among people who report the use of pesticides ${ }^{12}$ and smokers generally have a lower risk of developing $\mathrm{PD}^{13}$. As many products of oxidative stress and neurotoxins are detoxified by GST enzymes, decreased (impaired) detoxification capacity may result in an increased PD risk. The phenotypic absence of GSTM1 and GSTT1 activity is due to homozygous deletion of these genes ${ }^{11}$.

Oxidative stress activates GST (and its variants M1, T1 and P1) in order to detoxify many products of lipid, nucleic acid and protein oxidation. GSTM1 and GSTT1 catalyze detoxification of reactive oxygen and products of lipid peroxidation ${ }^{14}$.

Epidemiologic studies show that null genotypes for GSTM1 and GSTT1 are related to the increase of susceptibility to oxidative stress associated diseases ${ }^{15}$. Null genotype for GSTM1 (homozygote to the null allele) increases the risk for cancer in some tissues and it is also associated with $\mathrm{PD}^{16}$.

Evaluating studies have shown the impact of combined genetic polymorphisms and environmental factors in neurodegenerative diseases. Thorough studies should be conducted in various groups of population, in order to characterize smaller specific groups of PD susceptible individuals (for example, older patients whose survival time allows a cumulative effect of oxidative damage with genotoxic risk). This study aimed to analyze the frequency of GST genetic variations, including GSTT1 and GSTM1 in patients suffering from PD and to evaluate the association between GSTT1 and GSTM1 genotypes and their relation to the exposition to environmental toxins in those patients.

\section{METHODS}

A group of 423 individuals were selected and distributed in two groups: Study Group (SG) - 254 PD patients - and Control Group (CG) - 169 individuals with negative diagnosis for PD (controls). Mixed ethnicity was considered when those groups were created ${ }^{17}$, independently of gender, familial history PD or sporadic PD. Patients were selected at the Movement Disorders Clinic of the Hospital de Base of Faculdade de Medicina de São José do Rio Preto (FAMERP). Diagnosis of PD followed the criteria recommended by Jankovic $^{18}$, including bradykinesia, rigidity, tremor at rest, postural instability, unilateral onset, response to L-dopa for more than five years, levodopa-induced dyskinesia, progressive disorder, persistent asymmetry and clinical course of ten years or more, as well as complementary tests ${ }^{18}$. Controls were age matched with patients and were convened in the same institution. All subjects were informed about the nature of the study and confirmed their willingness to participate by signing written consent forms. The study was approved by the Ethics Research Committee of FAMERP (Protocol $n^{\circ} 151 / 2008$, Certificate of Appreciation Presentation Ethics CAAE $n^{\circ}$ 0029.0.140.000-08).

This was an experimental case-control study. Participants were submitted to an interview and invited to answer a questionnaire concerning personal data, lifestyle, previous pesticide exposure and age at the time of the first PD symptoms and other diseases. Peripheral blood was collected in order to obtain analysis of genetic polymorphisms for GSTT1 and GSTM1.

\section{Genetic analysis for GSTT1 and GSTM1}

The study of polymorphisms was performed in the Center for Research in Biochemistry and Molecular Biology of FAMERP and consisted of genomic DNA extraction from whole blood samples $^{19}$ and DNA amplification by conventional polymerase chain 
reaction (PCR). Customs assays were used to determine deletions in GSTM1 and GSTT1. Subjects were scored as either having one or two copies of the gene (non-null genotype), or as having two missing copies of the gene (null genotype). Genetic determinations were made blinded to PD status.

Each reaction was performed in Eppendorf Mastercycler Thermocycler, each tube contained $0.5 \mathrm{~mL}$ of nucleotides (0.8 mM), $2.5 \mathrm{~mL}$ of buffer PCR 10X, $2.5 \mathrm{~mL}$ of dimethyl sulfoxide $10 \%, 2.5 \mathrm{~mL}$ of each primer $(2.5 \mathrm{mM}), 0.2 \mathrm{~mL}$ of Taq polimerase ( $5 \mathrm{U} / \mathrm{mL}), 11 \mathrm{~mL}$ of Milli Q water, and $2 \mathrm{~mL}$ of diluted genomic DNA (0.2 mg). Primers used: GSTT1 sense: 5 AAC TCC CTA AAA GCT AAA C 3’; GSTT1 non-sense: 5’ GTT GGG CTC AAA TAT ACG GTG G 3’; GSTM1 sense: 5 ' TTC CTT ACT GGT CCT CAC ATC TC 3’; GSTM1 non-sense: 5’ TCA CCG ATC ATG GCC AGC A 3'. In the same reaction, CYP1A1 gene was used as control, presenting the following primers sequence, sense: 5’GAA CTG CCA CTT CAG CTG TCT 3'; non-sense: 5’ CAG CTG CAT TTG GAA GTG CTC 3’. Initial DNA denaturation will be obtained at $94^{\circ} \mathrm{C}$ during 4 minutes and the reaction mix submitted to 39 cycles of $94^{\circ} \mathrm{C}$ during 2 minutes and $59^{\circ} \mathrm{C}$ during 1 minute, extension at $72{ }^{\circ} \mathrm{C}$ during 1 minute and ending cycle at $72^{\circ} \mathrm{C}$ during 10 minutes $^{20}$.

GSTM1 and GSTT1 did not need enzymatic restriction, and were identified by the presence or the absence of the genes (null genotype). Post-PCR product was separated by $1.5 \%$ agarose gel electrophoresis, under constant electric current of $150 \mathrm{~V}$ during 45 minutes, separating 423 base pairs fragments (GSTT1), 310 base pairs (CYP control) and 230 base pairs (GSTM1). A standard DNA sample (100 base pairs - Invitrogen) was used as comparison to the electrophoretic bands. After the electrophoresis, the gel was stained by GelRed ${ }^{\circledR}$ (Uniscience) during 10 minutes and DNA fragments were visualized under ultraviolet light (UV) (Fig 1).

\section{STATISTICAL ANALYSIS}

The categorical variables including the allele and genotype frequencies for the GSTT1 and GSTM1 genotypes were analyzed applying the Fisher's exact test and the $\chi^{2}$ test. Statistical analysis also included Hardy-Weinberg equilibrium, $t$-test and multivariate regression analysis; $\mathrm{p}<0.05$ was considered statistically significant. Hardy-Weinberg equilibrium was assessed in cases and controls using the $\chi^{2}$ test. Departure from Hardy-Weinberg equilibrium may be indicative of genotyping error or non-random selection of controls in terms of the distribution of a given polymorphism.

\section{RESULTS}

The SG (PD patients) was generally younger $(69.2 \pm 11.1$ years old) than the CG $(71.7 \pm 8.0$ years old; $p=0.008)$. Male gender prevailed in SG in comparison to CG $(48 \%, \mathrm{p}=0.006)$. Fig 2 shows the analysis of smoking, drinking and pesticide exposure data. SG had higher smokers prevalence (43\%) than CG (36\%) - however not statistically relevant $(\mathrm{p}=0.225)$. Frequent alcohol consumption was also higher in SG (37\%), but it did not differ to CG (34\%; P=0.666). On the other hand, SG had a higher exposure to pesticides (48\%) than CG (32\%; 0.014).

Table 1 shows absence or presence of GSTM1 and GSTT1 in PD patients and controls. A similarity was found for both presence and absence of GSTT1 among patients (83 and $17 \%$, respectively) and controls ( 80 and $20 \%$; $=0.605$ ). For GSTM1 genotype, with $54 \%$ of frequency and $46 \%$ of absence in SG, versus 48 and $52 \%$ in controls ( $p=0.319$ ). GSTT 1 distribution showed the standard predicted by Hardy-Weinberg equilibrium in $\mathrm{SG}\left(\chi^{2}=1.7 ; \mathrm{p}<0.05\right)$ and $\mathrm{CG}\left(\chi^{2}=0.21 ; \mathrm{p}<0.05\right)$,
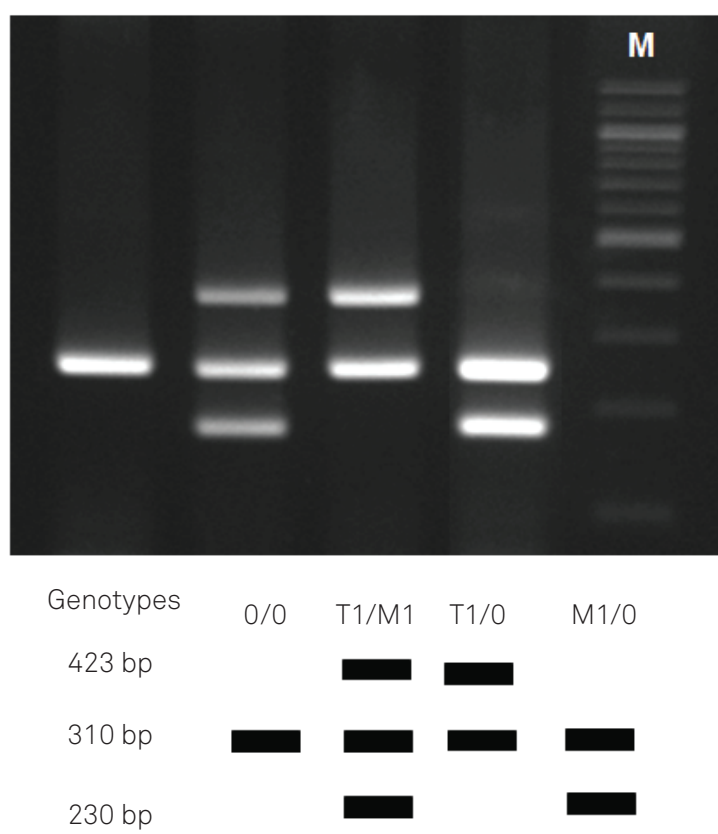

M: molecular marker (100 bp).

Fig 1. Diagram showing electrophoretic profile on agarose gel (1.5\%) to GSTT1 and GSTM1 genes, presenting the corresponding genotypes (presence or absence) to DNA fragments in base pairs.

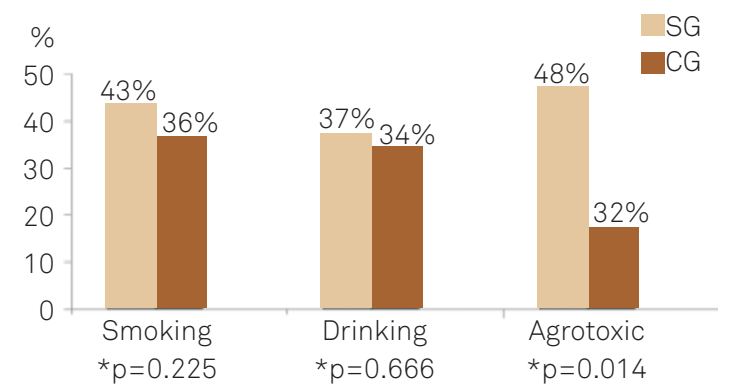

${ }^{\star} \chi^{2}$ test; SG: study group; CG: control group.

Fig 2. Distribution for smoking and drink habits, and previous contact with agrotoxic in patients with Parkinson disease and controls. 
the same occurred with GSTM1 (SG $-\chi^{2}=33.0 ; \mathrm{p}<0.05$ and $\left.\mathrm{CG}-\chi^{2}=12.0 ; \mathrm{p}<0.05\right)$.

Tables 2 to 4 show the distribution of groups according to the genetic variations and to environmental factors. Similarity in both groups occurred concerning smoking (Table 2) and drinking habits (Table 3). It was also observed a higher frequency of nullity for GSTT1 and GSTM1 (0/0) and contact to pesticides (18\%) in patients than CG $(13 \%$, $\mathrm{p}=0.014$; Table 4). Furthermore, SG showed higher frequency for nullity of genotypes $(0 / 0)$ combined with pesticides than GSTM1 (18 versus 6\%; $\mathrm{p}=0.010$ ). On the other hand, patients had lower frequency of the combination genotype nullity and absence of pesticides (4.2\%) compared to presence of GSTT1

Table 1. Allelic and genotypic frequency for glutathione S-transferase M1 and T1 genes in patients with Parkinson disease and controls.

\begin{tabular}{|c|c|c|c|c|c|}
\hline \multirow{2}{*}{ Genotype } & \multicolumn{2}{|c|}{ SG } & \multicolumn{2}{|c|}{$C G$} & \multirow{2}{*}{${ }^{*} p$-value } \\
\hline & $n$ & $\%$ & $n$ & $\%$ & \\
\hline \multicolumn{6}{|l|}{ GSTT1 } \\
\hline$+/+$ & 200 & 83 & 133 & 80 & \multirow{3}{*}{0.605} \\
\hline $0 / 0$ & 42 & 17 & 33 & 20 & \\
\hline Total & 242 & 100 & 166 & 100 & \\
\hline \multicolumn{6}{|l|}{ GSTM1 } \\
\hline$+/+$ & 130 & 54 & 80 & 48 & \multirow{3}{*}{0.319} \\
\hline $0 / 0$ & 112 & 46 & 86 & 52 & \\
\hline Total & 242 & 100 & 166 & 100 & \\
\hline
\end{tabular}

SG: study group; CG: control group; ${ }^{*} \chi^{2}$ test; +/+: presence; $0 / 0$ : absence
(45\%, $\mathrm{p}=0.0001$; Table 4). The same occurred in relation to the presence of both genotypes in patients with previous contact to pesticides (GSTM1/GSTT1=48\%), compared to nullity of genotypes (4.2\%; $\mathrm{p}=0.016)$ in patients without previous exposure to pesticides.

\section{DISCUSSION}

In this study, null genotypes for GSTM1 and GSTT1 showed similarity between SG (17 and 46\%, respectively) and CG (20 and 52\%, respectively). Nullity for GSTM1 and GSTT1 in both groups was near to the frequencies observed in a study with Pakistani population, which showed 42.1 and $25.4 \%$, respectively ${ }^{21}$. The homozygous deletion of these genes, which makes individuals more prone to environmental carcinogenic compounds, shows prevalence in GSTM1 within the world's population (frequency between 45 and 60\%), mainly in Caucasians, Asians, Spanish and Pakistanis ${ }^{21}$, while nullity for GSTT1 is much lower (between 20 and 23\%).

Brazilians form one of the most heterogeneous populations in the world, which is the result of five centuries of interethnic crosses of people from three continents: the European colonizers, mainly represented by the Portuguese, the African slaves, and the autochthonous Amerindians. Considering this fact, a specific dissection

Table 2. Distribution for patients with Parkinson disease in relation to glutathione S-transferases M1 and T1 genotypes, considering smoking habit.

\begin{tabular}{|c|c|c|c|c|c|c|c|c|c|}
\hline & \multicolumn{2}{|c|}{$\begin{array}{l}\text { Smoking } \\
\text { patient }\end{array}$} & \multicolumn{2}{|c|}{$\begin{array}{c}\text { No smoking } \\
\text { patient }\end{array}$} & \multicolumn{2}{|c|}{$\begin{array}{l}\text { Smoking } \\
\text { control }\end{array}$} & \multicolumn{2}{|c|}{$\begin{array}{l}\text { No smoking } \\
\text { control }\end{array}$} & \multirow[t]{2}{*}{${ }^{*} p$-value } \\
\hline & $\mathrm{n}$ & $\%$ & $n$ & $\%$ & $n$ & $\%$ & $n$ & $\%$ & \\
\hline $\mathrm{T} 1 / 0$ & 33 & 34.0 & 52 & 40.0 & 17 & 33.0 & 40 & 44.0 & 0.356 \\
\hline $\mathrm{M} 1 / 0$ & 10 & 11.0 & 7 & 5.0 & 4 & 8.0 & 7 & 8.0 & 0.440 \\
\hline $\mathrm{T} 1 \mathrm{M} 1$ & 42 & 43.0 & 63 & 47.0 & 22 & 43.0 & 35 & 39.0 & 0.995 \\
\hline $0 / 0$ & 12 & 12.0 & 11 & 8.0 & 8 & 16.0 & 8 & 9.0 & 1.000 \\
\hline Total & 97 & 100.0 & 133 & 100.0 & 51 & 100.0 & 90 & 100.0 & - \\
\hline
\end{tabular}

0/0:nullity for GSTT1 and GSTM1; *Fisher's or $\chi^{2}$ tests; Patientintragroup analysis:T1 versus $\mathrm{M} 1=0.209 ; \mathrm{T} 1$ versus T1M1 $=0.987 ; \mathrm{T} 1$ versus $0 / 0=0.360 ; \mathrm{M} 1$ versus T1 M1 $=0.233$ $\mathrm{M} 1$ versus $0 / 0=0.923 ; \mathrm{T} 1 \mathrm{M} 1$ versus $0 / 0=0.402$. Control intragroup analysis: $\mathrm{T} 1$ versus $\mathrm{M} 1=0.727 ; \mathrm{T} 1$ versus $\mathrm{T} 1 \mathrm{M} 1=0.429 ; \mathrm{T} 1$ versus $0 / 0=0.228 ; \mathrm{M} 1$ versus $\mathrm{T} 1 \mathrm{M} 1=1.000$; $\mathrm{M} 1$ versus $0 / 0=0.696 ; \mathrm{T} 1 \mathrm{M} 1$ versus $0 / 0=0.594$. Intergroup analysis: $\mathrm{T} 1$ versus $\mathrm{M} 1=1.000 ; \mathrm{T} 1$ versus $\mathrm{T} 1 \mathrm{M} 1=0.966 ; \mathrm{T} 1$ versus $0 / 0=0.843 ; \mathrm{M} 1$ versus $\mathrm{T} 1 \mathrm{M} 1=0.763 ; \mathrm{M} 1$ versus $0 / 0=0.717 ; \mathrm{T} 1 \mathrm{M} 1$ versus $0 / 0=0.848$.

Table 3. Distribution for patients with Parkinson disease in relation to glutathione S-transferases M1 and T1 polymorphisms, considering drinking habit.

\begin{tabular}{|c|c|c|c|c|c|c|c|c|c|}
\hline & \multicolumn{2}{|c|}{$\begin{array}{l}\text { Drinking } \\
\text { patient }\end{array}$} & \multicolumn{2}{|c|}{$\begin{array}{c}\text { No drinking } \\
\text { patient }\end{array}$} & \multicolumn{2}{|c|}{$\begin{array}{l}\text { Drinking } \\
\text { control }\end{array}$} & \multicolumn{2}{|c|}{$\begin{array}{l}\text { No drinking } \\
\text { control }\end{array}$} & \multirow[t]{2}{*}{${ }^{*} p$-value } \\
\hline & $\mathrm{n}$ & $\%$ & $\mathrm{n}$ & $\%$ & $\mathrm{n}$ & $\%$ & $\mathrm{n}$ & $\%$ & \\
\hline T1/0 & 28 & 33.6 & 57 & 38.5 & 13 & 29 & 43 & 45 & 0.291 \\
\hline $\mathrm{M} 1 / 0$ & 4 & 5.0 & 13 & 9.0 & 4 & 9 & 7 & 7 & 0.671 \\
\hline $\mathrm{T} 1 \mathrm{M} 1$ & 38 & 46.0 & 67 & 45.5 & 23 & 51 & 34 & 36 & 0.724 \\
\hline $0 / 0$ & 13 & 15.4 & 10 & 7.0 & 5 & 11 & 11 & 12 & 0.192 \\
\hline Total & 83 & 100 & 147 & 100.0 & 45 & 100 & 95 & 100 & - \\
\hline
\end{tabular}

0/0: nullity for GSTT1 and GSTM1; *Fisher's or $\chi^{2}$ tests; Patient intragroup analysis: T1 versus M1 =0.572; 11 versus T1M1=0.753; T1 versus $0 / 0=0.068 ; \mathrm{M} 1$ versus $\mathrm{T} 1 \mathrm{M} 1=0.413 ; \mathrm{M} 1$ versus $0 / 0=0.054 ; \mathrm{T} 1 \mathrm{M} 1$ versus $0 / 0=0.116$. Control intragroup analysis: $\mathrm{T} 1$ versus $\mathrm{M} 1=0.450 ; \mathrm{T} 1$ versus $\mathrm{T} 1 \mathrm{M} 1=0.079 ; \mathrm{T} 1$ versus $0 / 0=0.743$; $\mathrm{M} 1$ versus $\mathrm{T} 1 \mathrm{M} 1=1.000 ; \mathrm{M} 1$ versus $0 / 0=1.000 ; \mathrm{T} 1 \mathrm{M} 1$ versus $0 / 0=0.710$. Intergroup analysis: $\mathrm{T} 1$ versus $\mathrm{M} 1=0.423 ; \mathrm{T} 1$ versus $\mathrm{T} 1 \mathrm{M} 1=0.681 ; \mathrm{T} 1$ versus $0 / 0=1.000$; $\mathrm{M} 1$ versus $\mathrm{T} 1 \mathrm{M} 1=0.702 ; \mathrm{M} 1$ versus $0 / 0=0.382 ; \mathrm{T} 1 \mathrm{M} 1$ versus $0 / 0=0.577$. 
Table 4. Distribution for patients with Parkinson disease in relation to glutathione S-transferases M1 and T1 polymorphisms, considering previous contact with agrotoxic.

\begin{tabular}{|c|c|c|c|c|c|c|c|c|c|}
\hline & \multicolumn{2}{|c|}{$\begin{array}{l}\text { Agrotoxic } \\
\text { patient }\end{array}$} & \multicolumn{2}{|c|}{$\begin{array}{c}\text { No agrotoxic } \\
\text { patient }\end{array}$} & \multicolumn{2}{|c|}{$\begin{array}{l}\text { Agrotoxic } \\
\text { control }\end{array}$} & \multicolumn{2}{|c|}{$\begin{array}{c}\text { No agrotoxic } \\
\text { control }\end{array}$} & \multirow[t]{2}{*}{ *p-value } \\
\hline & $n$ & $\%$ & $\mathrm{n}$ & $\%$ & $n$ & $\%$ & $n$ & $\%$ & \\
\hline $\mathrm{T} 1 / 0$ & 32 & 28.0 & 53 & 45.0 & 10 & 43.0 & 20 & 42.0 & 0.840 \\
\hline $\mathrm{M} 1 / 0$ & 7 & 6.0 & 10 & 8.5 & 2 & 9.0 & 5 & 11.0 & 0.668 \\
\hline T1M1 & 55 & 48.0 & 50 & 42.3 & 8 & 35.0 & 16 & 34.0 & 0.144 \\
\hline $0 / 0$ & 21 & 18.0 & 5 & 4.2 & 3 & 13.0 & 6 & 13.0 & 0.014 \\
\hline Total & 115 & 100.0 & 118 & 100.0 & 23 & 100.0 & 47 & 100.0 & - \\
\hline
\end{tabular}

0/0: nullity for GSTT1 and GSTM1; *Fisher's test or $\chi^{2}$ tests; Patient intragroup analysis: T1 versus M1=0.784; T1 versus T1M1=0.060; T1 versus 0/0=0.0001; M1 versus $\mathrm{T} 1 \mathrm{M} 1=0.551 ; \mathrm{M} 1$ versus $0 / 0=0.010 ; \mathrm{T} 1 \mathrm{M} 1$ versus $0 / 0=0.016$. Control intragroup analysis: $\mathrm{T} 1$ versus $\mathrm{M} 1=1.000 ; \mathrm{T} 1$ versus $\mathrm{T} 1 \mathrm{M} 1=1.000 ; \mathrm{T} 1$ versus $0 / 0=1.000$; $\mathrm{M} 1$ versus $\mathrm{T} 1 \mathrm{M} 1=1.000 ; \mathrm{M} 1$ versus $0 / 0=1.000 ; \mathrm{T} 1 \mathrm{M} 1$ versus $0 / 0=1.000$. Intergroup analysis: $\mathrm{T} 1$ versus $\mathrm{M} 1=1.000 ; \mathrm{T} 1$ versus $\mathrm{T} 1 \mathrm{M} 1=0.224 ; \mathrm{T} 1$ versus $0 / 0=0.345 ; \mathrm{M} 1$ versus $\mathrm{T} 1 \mathrm{M} 1=0.602 ; \mathrm{M} 1$ versus $0 / 0=0.597 ; \mathrm{T} 1 \mathrm{M} 1$ versus $0 / 0=1.000$.

of the genetic contribution from each group represents serious theoretical difficulties ${ }^{22}$. In this study, individuals with such mixed ethnic background were selected, and both patients and controls showed a similar distribution of the nullity of GSTM1 and GSTT1. GSTT1 represents a protective factor for the individuals, because it is widely distributed in genotypes +/+ in both groups (83 and 80\% respectively). Absence of GSTM1 and of GSTT1 may also act on development of $\mathrm{PD}$, because there is no opposition to cellular oxidation. However, this condition is rare in the general population ${ }^{21}$.

Distribution of both genotypes (non-null and null) for GSTT1 and GSTM1 did not differ in this study when comparing a risk group (smokers and drinkers) to the unexposed group. In agreement with previous literature, including a meta-analysis by Tan et al. ${ }^{23}$ and Kiyohara et al. ${ }^{11}$. An early study of 100 PD cases and 200 controls reported that the protective effect of cigarette smoking was lost for patients with the GSTM1 deletion ${ }^{24}$. The GSTM1 null genotype expresses no enzyme activity; one could speculate that the loss of enzyme activity may enhance the protective effect conferred by a metabolite of cigarette smoke that is not metabolized due to lack of this enzyme. Accordingly, Wahner et al. ${ }^{25}$ noted a larger effect estimate for smokers with the homozygous deletion compared to smokers without the deletion, yet the confidence intervals largely overlapped due to the small sample sizes of the subgroups and the interaction analyses indicated no departure from multiplicativity.

On the other hand, greater exposition to pesticides in SG than CG was observed, with highlight to the combination of nullity for GSTT1/GSTM1 and exposition to pesticides in SG. Some studies reveal that certain pesticides (like rotenone) may induce $\mathrm{PC}$-specific symptoms ${ }^{26,27}$. Structurally and functionally, some types of pesticides act like inhibitors of mitochondrial complex I. In those cases, evidences show that dopaminergic neurons are vulnerable to mitochondrial disfunction ${ }^{28}$. Toxin is captured by dopamine transporters and noradrenalin remains stored inside the cell. As a consequence, the death of the cell is caused by the formation of reactive oxygen species and deficit in the mitochondrial respiratory chain ${ }^{11,28}$.

Exposition to environmental factors potentiates risk for PD, especially considering genetic factors. Studies show ethylene oxide or $\mathrm{n}$-hexane associated to a higher risk for neurotoxic effects, which suggests the relation with GST polymorphisms ${ }^{11}$. GST detoxified agents are, for example, polycyclic aromatic hydrocarbons, which may be found in pesticides ${ }^{11}$. Therefore, individuals with null genotype for GSTM1 and GSTT1 have a higher risk for oxidative stress associated diseases ${ }^{12,29}$, including $\mathrm{PD}^{10,16}$. However, there is little research on this matter, and even less on Brazilian individuals.

The possibility of selection bias is of concern in casecontrol studies. Although self-selection is unlikely to be related to genotype, selection factors related to environmental risk factors could bias estimates of main gene polymorphism effects. However, the gene-environment interaction estimates should not be influenced under the assumption that genotype does not influence participation conditional on exposure and disease, even if selection is jointly influenced by exposures and disease and whether or not the genotype is related to exposure, disease, or both ${ }^{25,30}$.

This study suggests the association between PD and previous pesticide exposure, the effects of which seem to be enhanced when combined with the nullity for GSTT1/ GSTM1. This demonstrates the relation between those genetic polymorphisms involved in the metabolism of xenobiotics and the environmental factors in PD. Alteration of biochemical markers related to oxidative stress in PD suggests its participation in this process, turning into a consequence or a cause of the disease.

\section{ACKNOWLEDGEMENTS}

The authors would like to thank Marcela Menezes do Carmo for technical support. 
1. Singh M, Khan AJ, Shah PP, et al. Polymorphism in environment responsive genes and association with Parkinson disease. Mol Cell Biochem 2008;312:131-138.

2. Korff A, Pfeiffer B, Smeyne M, et al. Alterations in glutathione S-transferase pi expression following exposure to MPP+-induced oxidative stress in the blood of Parkinson's disease patients. Parkinsonism Relat Disord 2011;17:765-768.

3. Dorsey ER, Constantinescu R, Thompson JP, et al. Projected number of people with Parkinson disease in the most populous nations, 2005 through 2030. Neurology 2007;68:384-386.

4. European Parkinson's Disease Association (EPDA). Priceless partnerships: annual report 2009 [cited 2013 May 3]. Available from: http://www.epda.eu.com/EasysiteWeb/getresource.axd?AssetID=10 $682 \&$ type =full\&servicetype=Attachment

5. Brasil. Ministério da Saúde. Departamento de Informática do SUS (DATASUS). Protocolo clínico e diretrizes terapêuticas: Doença de Parkinson. Portaria SAS/MS n²28, de 10 de maio de 2010 [cited 2013 May 3]. Available from: http://portal.saude.gov.br/portal/ arquivos/pdf/pcdt_doenca_parkinson_livro_2010.pdf

6. Moreira PI, Zhu X, Lee HG, et al. The (un)balance between metabolic and oxidative abnormalities and cellular compensatory responses in Alzheimer disease. Mech Ageing Dev 2006;127:501-506.

7. Vilar R, Coelho $H$, Rodrigues $E$, et al. Association of A313G polymorphism (GSTP1*B) in the glutathione S-transferase P1 gene with sporadic Parkinson's disease. Eur J Neurol 2007;14:156-161.

8. Smith MA, Rottkamp CA, Nunomura A, Raina AK, Perry G. Oxidative stress in Alzheimer's disease. Biochim Biophys Acta 2000;1502:139-144.

9. Maimone D, Dominici R, Grimaldi LME. Pharmacogenetics of neurodegenerative diseases. Eur J Pharmacol 2001;413:11-29.

10. Benmoyal-Segal L, Soreq H. Gene-environment interactions in sporadic Parkinson's disease. J Neurochem 2006;97:1740-1755.

11. Kiyohara C, Miyake Y, Koyanagi M, et al. GST polymorphisms, interaction with smoking and pesticide use, and risk for Parkinson's disease in a Japanese population. Parkinsonism Relat Disord 2010;16:447-452.

12. Priyadarshi A, Khuder SA, Schaub EA, Shrivastava S. A meta-analysis of Parkinson's disease and exposure to pesticides. Neurotoxicology 2000;21:435-440.

13. Ritz B, Ascherio A, Checkoway H, et al. Pooled analysis of tobacco use and risk of Parkinson disease. Arch Neurol 2007;64:990-997.

14. Uzunoglu S, Acar H, Okudan N, et al. Evaluation of the association between null genotypes of glutathione-S-transferases and Behcet's disease. Arch Dermatol Res 2006;297:289-293.

15. Onaran I, Osaydin A, Akbas F, et al. Are individuals with glutathione S-transferase GSST1 null genotype more susceptible to in vitro oxidative damage? J Toxicol Environ Health A 2000;59:15-26.
16. Stroombergen MC, Waring RH. Determination of glutathione S-transferase mu and theta polymorphisms in neurological disease. Hum Exp Toxicol 1999;18:141-145.

17. Pena SD, Bastos-Rodrigues L, Pimenta JR, Bydlowski SP. DNA tests probe the genomic anscestry of Brazilians. Braz $J$ Med Biol Res 2009;42:870-876.

18. Jankovic J. Parkinson's disease: clinical features and diagnosis. J Neurol Neurosurg Psychiatry 2008;79:368-376.

19. Salazar LA, Hirata MH, Cavalli SA, Machado MO, Hirata RD. Optimized procedure for DNA isolation from fresh and cryopreserved clotted human blood useful in clinical molecular testing. Clin Chem 1998;44:1748-1750.

20. Rossini A, Rapozo DC, Amorim LM, et al. Frequencies of GSTM1, GSTT1, and GSTP1 polymorphisms in a Brazilian population. Genet Mol Res 2002;1:233-240.

21. Shaikh RS, Amir M, Masood Al, et al. Frequency distribution of GSTM1 and GSTT1 null allele in Pakistani population and risk of disease incidence. Environ Toxicol Pharmacol 2010;30:76-79.

22. Parra FC, Amado RC, Lambertucci JR, et al. Color and genomic ancestry in Brazilians. Proc Natl Acad Sci 2003;100:177-182.

23. Tan EK, Khajavi M, Thornby JI, et al. Variability and validity of polymorphism association studies in Parkinson's disease. Neurology 2000;55:533-538.

24. De Palma G, Mozzoni P, Mutti A, Calzetti S, Negrotti A. Case-control study of interactions between genetic and environmental factors in Parkinson's disease. Lancet 1998;352:1986-1987.

25. Wahner AD, Glatt CE, Bronstein JM, Ritz B. Glutathione S-transferase mu, omega, pi, and theta class variants and smoking in Parkinson's disease. Neurosci Lett 2007;413:274-278.

26. Nisticò R, Mehdawy B, Piccirilli S, Mercuri N. Paraquat- and rotenone-induced models of Parkinson's disease. Int J Immunopathol Pharmacol 2011;24:313-322.

27. Xiong $\mathrm{N}$, Long $\mathrm{X}$, Xiong $\mathrm{J}$, et al. Mitochondrial complex I inhibitor rotenone-induced toxicity and its potential mechanisms in Parkinson's disease models. Crit Rev Toxicol 2012;42:613-632.

28. Reale M,Pesce M, Priyadarshini M, Kamal MA, Patruno A. Mitochondria as an easy target to oxidative stress events in Parkinson's disease. CNS Neurol Disord Drug Targets 2012;11:430-438.

29. Yuille M, Condie A, Hudson C, et al. Relationship between glutathione S-transferase M1, T1, and P1 polymorphisms and chronic lymphocytic leukemia. Blood 2002;99:4216-4218.

30. Morimoto LM, White E, Newcomb PA. Selection bias in the assessment of gene-environment interaction in case-control studies. Am J Epidemiol 2003;158:259-263. 